\title{
Biogeochemical cycling and ecological thresholds in a High Arctic lake (Svalbard)
}

\author{
Tomi P. Luoto $^{1}$ (1) $\cdot$ Marttiina V. Rantala ${ }^{2}$ E. Henriikka Kivilä ${ }^{3} \cdot$ Liisa Nevalainen $^{1} \cdot$ Antti E. K. Ojala $^{4}$
}

Received: 4 October 2018 / Accepted: 6 February 2019 / Published online: 20 February 2019

(c) The Author(s) 2019

\begin{abstract}
Lakes are a dominant feature of the Arctic landscape and a focal point of regional and global biogeochemical cycling. We collected a sediment core from a High Arctic Lake in southwestern Svalbard for multiproxy paleolimnological analysis. The aim was to find linkages between the terrestrial and aquatic environments in the context of climate change to understand centennial-long Arctic biogeochemical cycling and environmental dynamics. Two significant thresholds in elemental cycling were found based on sediment physical and biogeochemical proxies that were associated with the end of the cold Little Ice Age and the recent warming. We found major shifts in diatom, chironomid and cladoceran communities and their functionality that coincided with increased summer temperatures since the 1950s. We also discovered paleoecological evidence that point toward expanded bird (Little Auk) colonies in the catchment alongside climate warming. Apparently, climate-driven increase in glacier melt water delivery as well as a prolonged snow- and ice-free period have increased the transport of mineral matter from the catchment, causing significant water turbidity and disappearance of several planktonic diatoms and clear-water chironomids. We also found sedimentary accumulation of microplastic particles following the increase in Little Auk populations suggesting that seabirds potentially act as biovectors for plastic contamination. Our study demonstrates the diverse nature of climate-driven changes in the Arctic lacustrine environment with increased inorganic input from the more exposed catchment, larger nutrient delivery from the increased bird colonies at the surrounding mountain summits and subsequent alterations in aquatic communities.
\end{abstract}

Keywords Bird guano $\cdot$ Carbon $\cdot$ Chironomidae $\cdot$ Diatoms $\cdot$ Microplastic $\cdot$ Nitrogen

\section{Introduction}

Climate change alters biogeochemical cycling of major elements and nutrients, especially in regions with sparse vegetation, which are particularly sensitive to changes in surface energy and water balance (Zepp et al. 2007). This

Tomi P. Luoto

tomi.luoto@helsinki.fi

1 Faculty of Biological and Environmental Sciences, Ecosystems and Environment Research Programme, University of Helsinki, Niemenkatu 73, 15140 Lahti, Finland

2 Institute of Earth Surface Dynamics, University of Lausanne, CH1015 Lausanne, Switzerland

3 Department of Biological and Environmental Science, University of Jyväskylä, P.O. Box 35, 40014 Jyvaskyla, Finland

4 Geological Survey of Finland, Betonimiehenkuja 4, 02150 Espoo, Finland phenomenon is most visible in the Polar Regions, where a recent pan-arctic greening of the tundra has been observed (Wookey et al. 2009). In addition to increasingly productive freshwater systems in the Arctic (Michelutti et al. 2005; Holmgren et al. 2010), in some regions, changes in the water balance and cryogenic processes have caused disappearance of lakes (Bouchard et al. 2013; Linderholm et al. 2018) as well as formation of new freshwater ecosystems known as permafrost thaw ponds (Vonk et al. 2015). Climate-driven biological reorganizations in the Arctic include increased primary production owing to longer summer growing seasons, increased algal habitat availability and enhanced catchment nutrient fluxes (Wrona et al. 2016). For example, melting permafrost will likely cause a release of nutrients into inlet streams driving changes in the ecosystem structure of lakes (Hobbie et al. 1999; Thienpont et al. 2013).

Another factor causing nutrient enrichment of Arctic lakes and their catchments is influence of climate on bird populations, as seabirds increasingly transport nutrients 
from the marine environment to their terrestrial nesting areas (Côté et al. 2010; Hargan et al. 2017), a phenomenon known as ornithogenic drainage (Smol 2016). Climate-mediated physical disturbances, such as changes in underwater light availability and thermal stability due to increased loading of organic or minerogenic matter from the terrestrial environment, may also lead to major disruptions to aquatic community structures (Vincent and Pienitz 1996; Nevalainen et al. 2015). In addition to enhanced biogeochemical cycling, greening terrestrial landscape and increasingly productive ecosystems (Forbes et al. 2010), accumulation of microplastic, especially in the oceans (Cole et al. 2011), is an increasing threat in the Arctic areas (Lusher et al. 2015). Besides the marine environment, microplastic particles are also transported to freshwater ecosystems, particularly in coastal areas, via the atmosphere or by biovectors, such as birds feeding in the ocean (Eerkes-Medrano et al. 2015; Horton et al. 2017; Provencher et al. 2018). Microplastic particles cause threat to freshwater organisms through physiological problems (ingestion and digestion) and ecotoxicological effects (Dris et al. 2015). Although microplastics have been encountered even in remote arctic areas (Lusher et al. 2015), their distribution in High Arctic lakes is still mostly unknown.

Since observational records in the Arctic are scarce and short, indirect paleolimnological methods are required to reveal long-term environmental dynamics in high latitude lakes and their surroundings (Smol 2016). The paleolimnological record in surface and downcore lake sediments is based primarily on various physical and biogeochemical proxies and biological indicators, such as diatoms (Bacillariophyta) (Rühland et al. 2003; Rantala et al. 2017), chironomids (Diptera) (Quinlan et al. 2005; Luoto et al. 2019) and cladocerans (Crustacea) (Sweetman et al. 2008; Thienpont et al. 2015; Nevalainen et al. 2016). Physical proxies provide valuable lithological information, whereas biogeochemical proxies are particularly useful in tracking elemental cycling and lake-catchment interactions, such as bird effects using the sediment $\delta^{15} \mathrm{~N}$ signature (Stewart et al. 2013; Hargan et al. 2017). Diatoms are known to respond to $\mathrm{pH}$ and nutrient conditions (Tammelin et al. 2017; Pla-Rabés and Catalan 2018), chironomids to hypolimnetic oxygen and temperature (Quinlan and Smol 2002; Engels et al. 2014) and cladocerans to water quality and habitat changes (Jeppesen et al. 2011; Nevalainen 2012). The use of these paleolimnological proxies has enhanced understanding of the trajectories of climate-induced changes in northern aquatic ecosystems. Applying the multiproxy paleolimnological approach it is possible to assess long-term interactions between aquatic systems and their watersheds, i.e. lake-catchment coupling, and to find connections between different environmental realms, including the terrestrial, marine and atmospheric environments.
In this study, we analyzed fossil algal (diatoms) and invertebrate (chironomids, cladocerans and oribatid mites) communities together with physical (magnetic susceptibility, organic content), biogeochemical (carbon, nitrogen and their stable isotopes) and ecotoxicological (microplastics) proxies from a sediment profile collected from a High Arctic Lake Revvatnet in Svalbard $\left(77^{\circ} \mathrm{N}\right)$. The aim was to build holistic understanding on long-term Arctic biogeochemical cycling and lake ecosystem shifts under the climate warming since the Little Ice Age. We hypothesize that long-term changes are climate-driven, but expect a complex interplay between varied environmental controls and multiple responses of the Arctic ecosystem. The study provides insights into linkages between the atmospheric, terrestrial and freshwater environments but also on the marine-derived influence, since extensive seabird colonies occupy the lake catchment area.

\section{Study site}

Lake Revvatnet $\left(77.022^{\circ} \mathrm{N}, 15.368^{\circ} \mathrm{E}\right)$ is located in Hornsund, High Arctic Svalbard (Fig. 1a). Revvatnet is a glacial lake situated close to the Polish Polar Station Hornsund in an area characterized by pristine Arctic tundra and polar desert. The lake has infertile rocky shores, and a maximum depth of $26 \mathrm{~m}$ in the southern main basin (Fig. 1b). Based on epilimnetic limnological measurements at the end of July 2013, the water color was 0 PCU, $\mathrm{pH} 7.6$, dissolved oxygen (DO) content $9.1 \mathrm{mg} \mathrm{l}^{-1}$, specific conductivity $30 \mu \mathrm{g}^{-1}$ and total dissolved solids (TDS) $10 \mu \mathrm{g} \mathrm{l^{-1 }}$. Arctic char (Salvelinus alpinus) were observed living in Revvatnet. Continuous water mixing occurs in Revvatnet during the summer, while it ceases during the winter when the lake freezes over (Nowiński and Wiśniewska-Wojtasik 2006). Revvatnet, which lies at an elevation of $30 \mathrm{~m}$ a.s.l. and has a surface area of about $0.9 \mathrm{~km}^{2}$, is an overflow lake (Karczewski et al. 1981) with a network of streams and creeks entering from north and an outlet (Revelva) draining to Hornsund fjord (ocean bay) in the south (Fig. 1c).

The average present-day summer air temperature (June-August) in the area is $4.4{ }^{\circ} \mathrm{C}$ and the average annual precipitation is $<400 \mathrm{~mm}$ (Marsz and Styszyńska 2013). An increase in summer air temperature $\left(\sim 2^{\circ} \mathrm{C}\right)$ since 1979 has been meteorologically observed (Marsz and Styszyńska 2013), but the biologically active vegetation period still lasts only $\sim 2$ months. The periglacial tundra catchment of Revvatnet lies on the Revbotnen and Revdalen post-glacial marine terraces between the Hornsund fjord and the mountain summits (Fig. 1c). The terrain consists of outwash plains and undulating ground moraine with sporadic marginal and lateral ridges, whereas hillsides feature solifluction lobes and talus cones. Barnacle geese (Branta leucopsis) are abundant in the adjacent Fuglebergsletta and extensive Little 


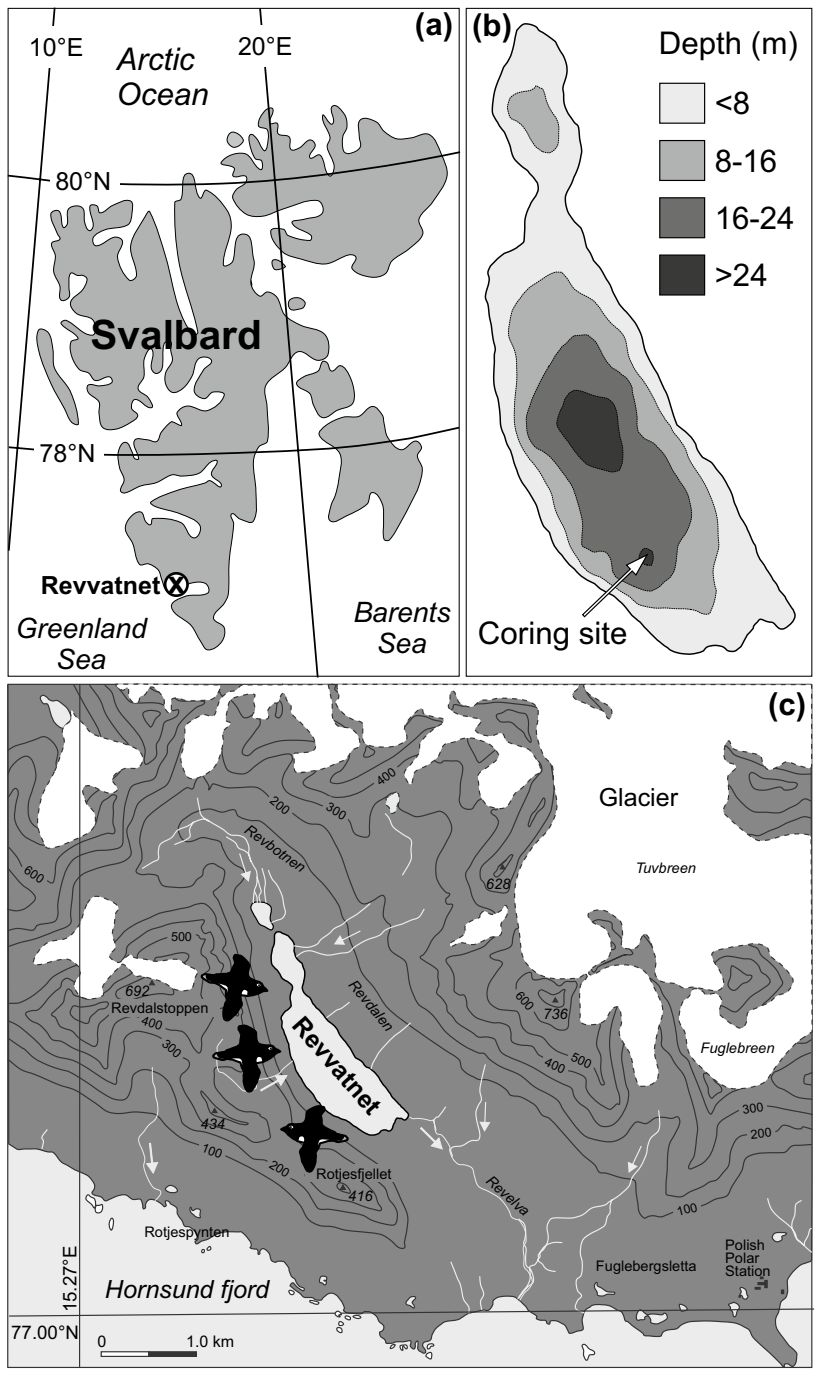

Fig. 1 The study site Revvatnet in Hornsund, Svalbard (a), bathymetric map and coring site (white arrow) (b) and catchment characteristics (c). Locations of Little Auk colonies are marked with bird symbols

Auk (Alle alle) colonies are present on the mountain slopes of Revdalstoppen and Rotjesfjellet, which drain into the lake. A recent expansion of bird colonies along the Hornsund coast has been observed (Wojczulanis-Jakubas et al. 2008; Zmudczyńska et al. 2009). The expansion of Little Auk colonies in the area appears to have begun during the early twentieth century (Gąsiorowski and Sienkiewicz 2019).

\section{Materials and methods}

\section{Sediments, chronology and sedimentological analyses}

Of the collection of several sediment cores from Lake Revvatnet by Ojala et al. (2016), a 30-cm sediment profile RE2, taken from the southern part of the main basin, was used in the present study. We selected this specific core for the present study because of its distant location from the network of streams in the north (Revbotnen, Fig. 1) to avoid the dominant effect of stream sediments and to capture a variety of environmental changes and lake-catchment dynamics. The sampling was performed in June 2013 from a boat with a Kajak corer (Renberg 1991) and the sediments were subsampled at $0.5-1 \mathrm{~cm}$ intervals at the lake shore. Water depth at the coring site was $23.5 \mathrm{~m}$.

For chronological control, ${ }^{137} \mathrm{Cs}$ analysis was performed at the Geological Survey of Finland using an EGandG Ortec ACE TM-2 K gamma spectrometer equipped with a four-inch NaI/TI detector. The core was logged for magnetic susceptibility (Dearing 1999) with a Bartington MS2E1 surface-scanning sensor and subsampled for loss on ignition (LOI, $+550{ }^{\circ} \mathrm{C}$ for $2 \mathrm{~h}$ ) at $1 \mathrm{~cm}$ resolution (Dean 1974).

\section{Biogeochemical and microplastic analyses}

Prior to the carbon analyses from sediment bulk organic matter, the fresh sediment was subjected to acid fumigation to remove carbonates, whereas nitrogen analyses were performed from natural sediment. Subsamples of 2-4 mg of freeze-dried and homogenized lake sediments were weighed and packed into tin capsules for elemental and stable isotope $\left(\delta^{13} \mathrm{C}, \delta^{15} \mathrm{~N}\right)$ composition of organic matter. $1-\mathrm{cm}$ sample resolution was used in less compacted surface samples at $0-8 \mathrm{~cm}$ depth, whereas the lower part of the core was analyzed with $0.5 \mathrm{~cm}$ resolution. The analyses were performed with a FlashEA 1112 elemental analyser coupled with a Thermo Finnigan DELTA plus Advantage mass spectrometer. The results are expressed as delta values $\delta^{13} \mathrm{C}$ and $\delta^{15} \mathrm{~N}(\%)$, described as $\delta=\left(\mathrm{R}_{\text {sample }} /\right.$ $\left.\mathrm{R}_{\text {standard }}-1\right) \times 1000$, where $\mathrm{R}$ equals ${ }^{13} \mathrm{C} /{ }^{12} \mathrm{C}$ and ${ }^{15} \mathrm{~N} /{ }^{14} \mathrm{~N}$, respectively. The reference standards are Vienna Pee Dee Belemnite for $\mathrm{C}$ and atmospheric $\mathrm{N}_{2}$ for $\mathrm{N}$. Proportions of organic $\mathrm{C}$ and total $\mathrm{N}(\%)$ in organic matter were also used in the calculation of the $\mathrm{C}_{\text {org }} / \mathrm{N}_{\text {tot }}$ mass ratio that can be used as a source (allochthonous/autochthonous) indicator of organic matter (Meyers and Teranes 2001).

Topmost $10 \mathrm{~cm}$ were analyzed for microplastic particles using microscopic separation for identification and 
classification (Karlsson et al. 2017). Plastic contamination from sampling and storage was avoided and controlled visually at identification. The separated size fractions included $100-500 \mu \mathrm{m}, 500-1000 \mu \mathrm{m}$ and $>1000 \mu \mathrm{m}$ (Löder and Gerdts 2015). Therefore, since particles smaller than $100 \mu \mathrm{m}$ were not analyzed, sample contamination from nanoplastics originating from e.g. clothing, sample storage and preparation was minimized. The results are expressed as number of plastic particles found per $1 \mathrm{~cm}^{3}$ of dry sediment.

\section{Diatom analysis}

Samples for diatom analysis were prepared following standard procedures as described in Battarbee et al. (2001). The samples were analyzed using a $2-\mathrm{cm}$ resolution. Organic matter was removed by oxidizing sediment samples with hydrogen peroxide $\left(30 \% \mathrm{H}_{2} \mathrm{O}_{2}\right)$ followed by removal of carbonates with hydrochloric acid $(37 \% \mathrm{HCl})$. Coarse minerogenic matter was removed physically by swirling the sample solution in a beaker and decanting the diatom suspension. The sample residue was checked for absence of diatom valves prior to disposal. Samples were dried on coverslips and mounted with Naphrax, and a minimum of 300 diatom valves per sample were identified with a light microscope at $1000 \times$ magnification. Taxonomic determination was mainly based on the flora of Krammer and Lange-Bertalot (1986, 1988, 1991a, b), with nomenclature updated where relevant due to taxonomic refinements.

\section{Chironomid and cladoceran analyses}

Standard methods were applied to fossil chironomid analysis (Brooks et al. 2007). The samples were analyzed using a $1-\mathrm{cm}$ resolution. The wet sediment was sieved through a mesh $(100-\mu \mathrm{m})$ and the residue was examined under a stereomicroscope ( $25 \times$ magnification). Larval head capsules were extracted and mounted permanently with Euparal on microscope slides. Taxonomic identification following Brooks et al. (2007) was performed under a light microscope (400 $\times$ magnification). The minimum chironomid head capsule number per sample was set to 50 (Heiri and Lotter 2001; Larocque 2001; Quinlan and Smol 2001). Alongside chironomid analysis, remains of cladocerans were picked and identified according to Szeroczyñska and Sarmaja-Korjonen (2007) and also oribatid mites were calculated following the procedure for environmentally extreme downcore sites (Luoto et al. 2013).

\section{Statistical methods and data utilization}

Hierarchical clustering was applied to separate stratigraphical diatom and chironomid zones. In the constrained cluster analysis, we used the unweighted paired group method with arithmetic mean (UPGMA) as the algorithm and Bray-Curtis as the similarity index (dissimilarity threshold of 0.5 for a zone to be included). The clustering was carried out using the program Past3 (Hammer et al. 2001). Due to linear nature of the assemblage data, principal component analysis (PCA) was used to examine variation in diatom and chironomid communities. The species data were $\log 10$ transformed prior to these analyses. The PCAs were carried out using the program Canoco 5 (Šmilauer and Lepš 2014). Diversity was assessed using the N2 effective number of occurrences (Hill 1973).

In addition to taxonomic assemblages, the diatom and chironomid data were examined for functional classification using ecological guilds and applying methodologies for algal (Rimet and Bouchez 2012) and macroinvertebrate (Schmera et al. 2017) functional ecology. The functional classification of diatoms was based on ecological guilds as delineated by Passy (2007) and Rimet and Bouchez (2012), including low profile taxa positioned at the bottom of the biofilm firmly attached to their substrate, high profile taxa extending to the upper layers of the biofilm (including colony forming diatoms), motile taxa capable of fast movement, and planktonic taxa. Each guild comprises taxa having developed diverse strategies to exploit resources and adapt to abiotic factors in a given environment, particularly with reference to nutrients, light, and physical disturbance. The chironomid feeding groups, including collector-gatherers and collector-filterers, were based on Merritt and Cummins (1996) and Mandaville (2002). As indicators for bird-impact, we used relative percentages of nitzschioid diatoms (Jones and Birks 2004; Keatley et al. 2009) and chironomids typical for lakes with significant bird influence in Svalbard, such as Orthocladius trigonolabis-type, O. consobrinus-type and Metriocnemus eurynotus-type (Brooks and Birks 2004; Luoto et al. 2016; Luoto and Ojala 2018).

To represent climate variability in Svalbard over the recent centuries, we used the data published by D'Andrea et al. (2012). Summer (June-August) temperature reconstructions are based on alkenone unsaturation in Lake Kongressvatnet, western Svalbard. To depict general trends, we used LOESS smooth with a span 0.2. The temperature data were obtained from the World Data Center for Paleoclimatology and NOAA's National Climatic Data Center, Paleoclimatology Branch website (http://www.ncdc.noaa.gov/ paleo/paleo.html). The chronologies were matched using the ${ }^{137}$ Cs peak in the Revvatnet RE2 sediment profile and further extrapolated deeper into the past.

\section{Results}

The ${ }^{137}$ Cs stratigraphy of the present sediment core RE2 was found to be very similar with other ${ }^{137} \mathrm{Cs}$ stratigraphies in Svalbard (Appleby 2004; Chu et al. 2006; Luoto et al. 2015) 
as well as other cores taken from Revvatnet and nearby Svartvatnet (Ojala et al. 2016). The ${ }^{137} \mathrm{Cs}$ activity in the RE2 core is well resolved with a single peak at the depth of $5.5-4.5 \mathrm{~cm}$ (Fig. 2). The peak can be linked with the atmospheric testing of nuclear weapons, with the onset of cesium fallout in the early 1950s and maximum fallout in 1963 CE. Therefore, the age horizon of $\sim 1950 \mathrm{CE}$ was assigned to

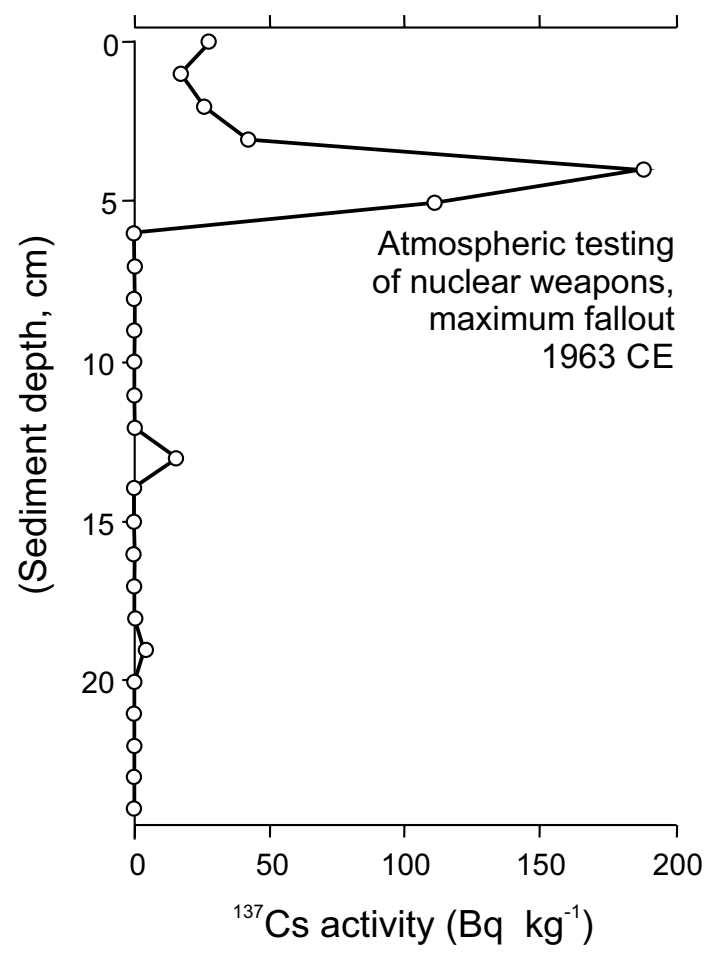

Fig. $2{ }^{137}$ Cs activity in the sediment profile from Revvatnet, Svalbard the sample at $5 \mathrm{~cm}$. Chronological extrapolation provides an age estimate of $\sim 1720 \mathrm{CE}$ for the bottom core, but since the lower part of the sediment profile lacks chronological control, this estimate is uncertain. Considering the potential increase in recent sedimentation rates (Ojala et al. 2016), the extrapolated ages are more likely older than younger.

The physical and biogeochemical proxies showed rather consistent changes in the Revvatnet sediment profile (Fig. 3) and were partly linkable with changes in diatom and chironomid assemblages and summer temperature increase. In the initial part of the core $(29-19 \mathrm{~cm})$, magnetic susceptibility was low $\left(10-14 \mathrm{SI} \times 10^{-5}\right)$ but began to increase towards the present $\left(>20 \mathrm{SI} \times 10^{-5}\right)$. A similar pattern was observed with $\delta^{13} \mathrm{C}$ (from -29 to $-25 \%$ ). In contrast, organic matter content (measured as LOI) was high in the initial phase (6-11\%) but low between 18 and $0 \mathrm{~cm}(4-6 \%)$. Similar to organic matter, also total organic $\mathrm{C}(-0.7$ to $1.4 \%)$, total $\mathrm{N}$ $(0.1-0.2 \%)$ and $\mathrm{C}_{\text {org }} / \mathrm{N}_{\text {tot }}(-8.2$ to 8.5$)$ showed lower values in the upper sediment profile, with thresholds at 18 and $6 \mathrm{~cm} . \delta^{15} \mathrm{~N}$ values had a deviating pattern showing a decreasing trend from the bottom core (from $\sim 3$ to $1 \%$ ) until a general increase in values from $10 \mathrm{~cm}$ onwards (mostly $>3 \%$ ).

From the sediment samples of Revvatnet, 89 diatom taxa were identified. The most abundant taxa included Cyclotella rossii-comensis-tripartita complex (mean abundance 18.7\%, maximum abundance 48.0\%), Pseudostaurosira brevistriata (10.6\%, 21.9\%) and Achnanthidium minutissimum (7.0\%, $20.3 \%$ ). According to the cluster analysis, four diatom zones (I-IV) were separated (Fig. 4). In zone I between 28 and $16 \mathrm{~cm}$, C. rossii-comensis-tripartita complex dominated and also P. brevistriata and Stauroneis anceps were common. In zone II between 14 and $10 \mathrm{~cm}, P$. brevistriata became the most abundant taxon, while $C$. rossii-comensis-tripartita

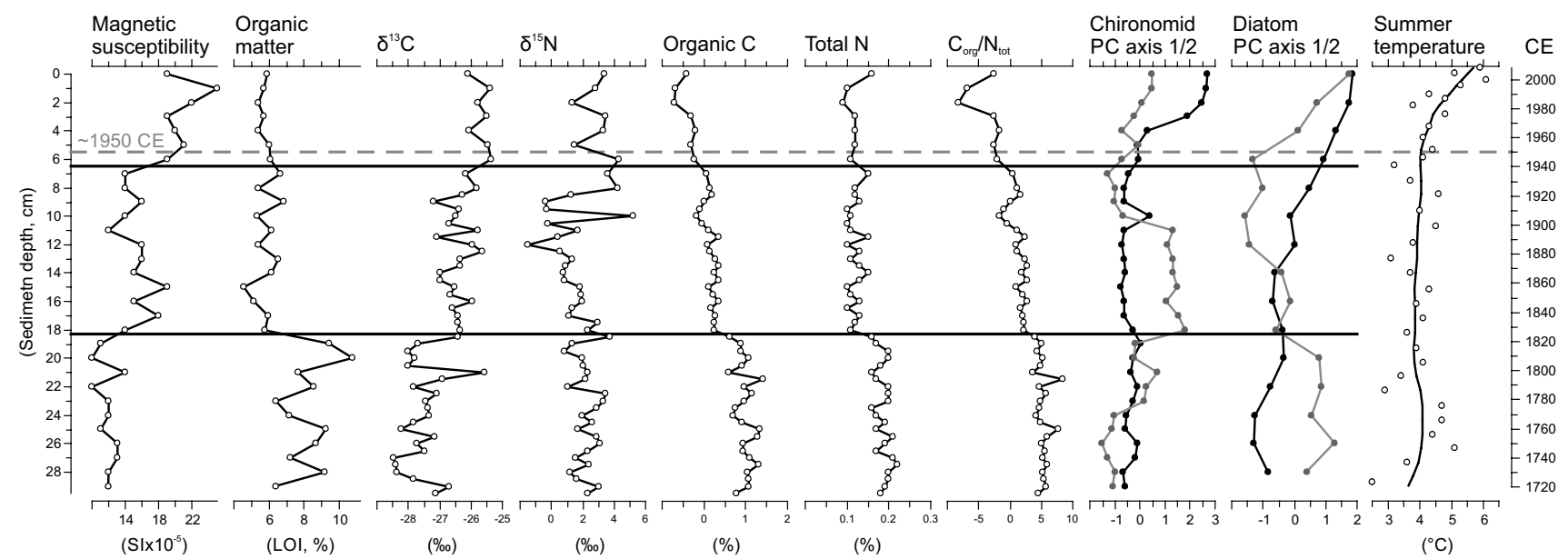

Fig. 3 Physical and biogeochemical sediment proxies compared with chironomid and diatom principal component (PC) axes 1 (black) and 2 (grey) scores. The temperature series using LOESS smoothing (span 0.2) is the sedimentary alkenone-based June-August air tem- perature reconstruction from Svalbard (D'Andrea et al. 2012). The secondary axis is aligned with the ${ }^{137} \mathrm{Cs}$ horizon of the Revvatnet record (grey dashed horizontal line). Older extrapolated sediments are not reliably dated 


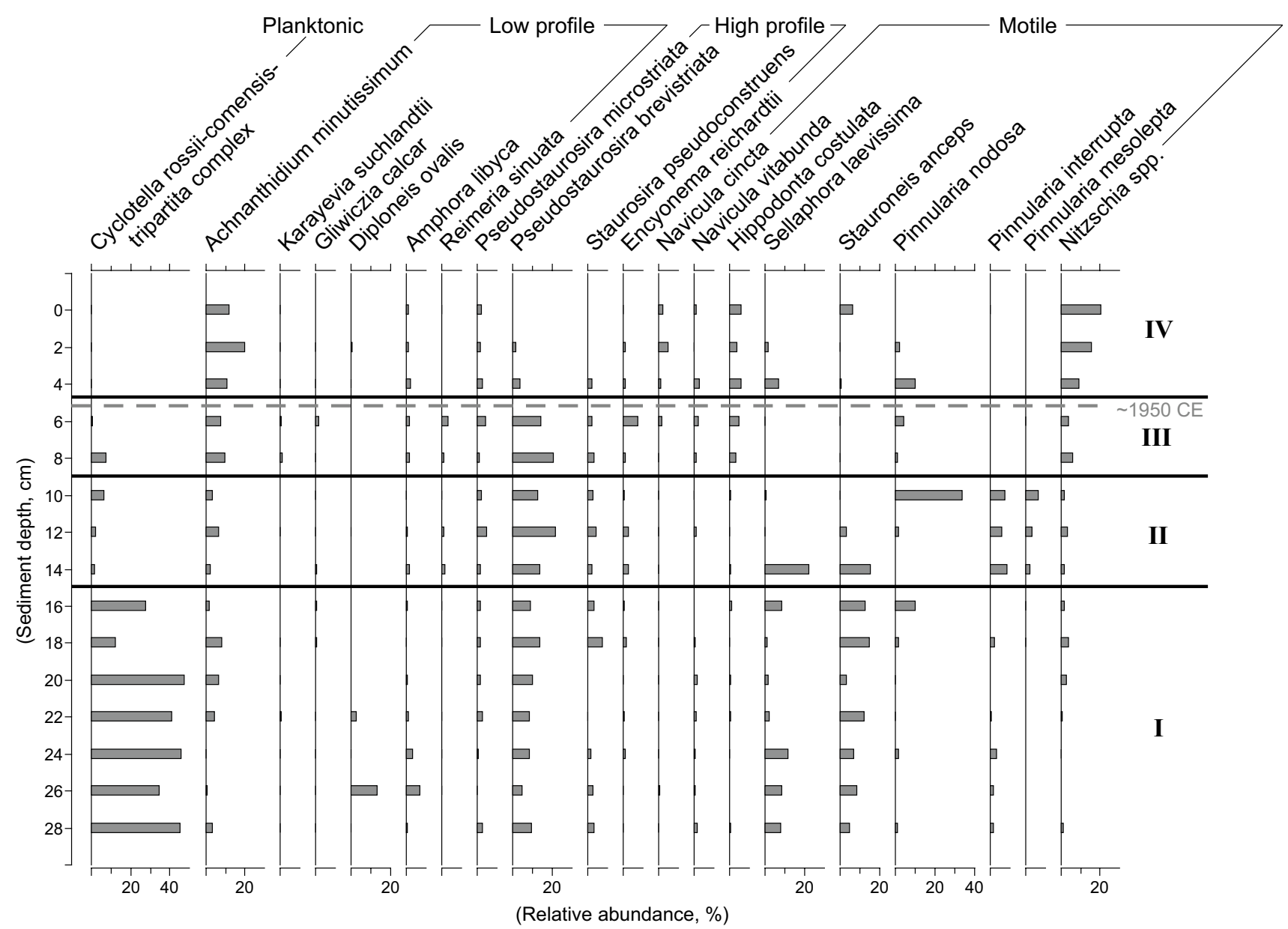

Fig. 4 Diatom stratigraphy of the most common taxa $(\mathrm{N} \geq 10, \min \geq 5)$ in Revvatnet grouped according to their ecological guilds. The floral zones (I-IV) were established using cluster analysis and the age horizon (grey dashed line) using ${ }^{137} \mathrm{Cs}$ analysis

complex markedly decreased. P. brevistriata continued to thrive in zone III between 8 and $6 \mathrm{~cm}$, where taxa such as A. minutissimum and Hippodonta costulata also increased. Zone IV between 4 and $0 \mathrm{~cm}$ (from $~ 1950 \mathrm{CE}$ until present) was dominated by A. minutissimum and Nitzschia spp. with simultaneous disappearances of the generally most abundant taxa $C$. rossii-comensis-tripartita complex and $P$. brevistriata.

The Revvatnet invertebrate stratigraphy consisted of 14 chironomid taxa, 1 cladoceran taxon and sporadic findings of oribatid mites. The most abundant chironomids included Oliveridia tricornis (mean abundance 50.7\%, maximum abundance $90.4 \%$ ), Micropsectra radialis-type (25.1\%, $81.8 \%)$ and Hydrobaenus lugubris-type $(11.6 \%, 38 \%)$. Similarly and almost concurrently with diatoms, four chironomid zones (I-IV) were separated (Fig. 5). Zone I between 29 and $19 \mathrm{~cm}$ was dominated by $O$. tricornis and M. radialistype. In zone II between 18 and $11 \mathrm{~cm}, M$. radialis-type disappeared and $O$. tricornis continued to dominate with H. lugubris-type. Zone III between 10 and $4 \mathrm{~cm}$ resembled zone I, as $M$. radialis-type returned to the stratigraphy with high abundances. In the topmost zone I between 3 and $0 \mathrm{~cm}$, previously predominant $O$. tricornis disappeared and $M$. radialis-type decreased. Orthocladius trigonolabis-type distinctly increased together with another member from the same genus, $O$. consobrinus-type. Similar to $O$. tricornis, the only cladoceran taxon, Chydorus sphaericus-type, disappeared permanently from the stratigraphy at $3 \mathrm{~cm}$.

Due to relatively short gradient lengths in the diatom (2.0 SD) and chironomid (2.4 SD) data, linear ordination method (PCA) was used (Šmilauer and Lepš 2014). The first diatom PC axis $\left(\lambda_{1}=0.37\right)$ explained $37.0 \%$ and the second axis $\left(\lambda_{2}=0.16\right) 16.3 \%$ of all variance. The first chironomid PC axis $\left(\lambda_{1}=0.40\right)$ explained $39.9 \%$ and the second axis $\left(\lambda_{2}=0.30\right) 30.2 \%$ of the total variance. According to the primary axis scores, both diatoms and chironomids had negatives score in the initial part of the stratigraphy and high scores at the topmost samples (Fig. 6). In case of axis 2 scores, diatoms showed a decreasing trend from the bottom samples until the scores began to increase towards the 


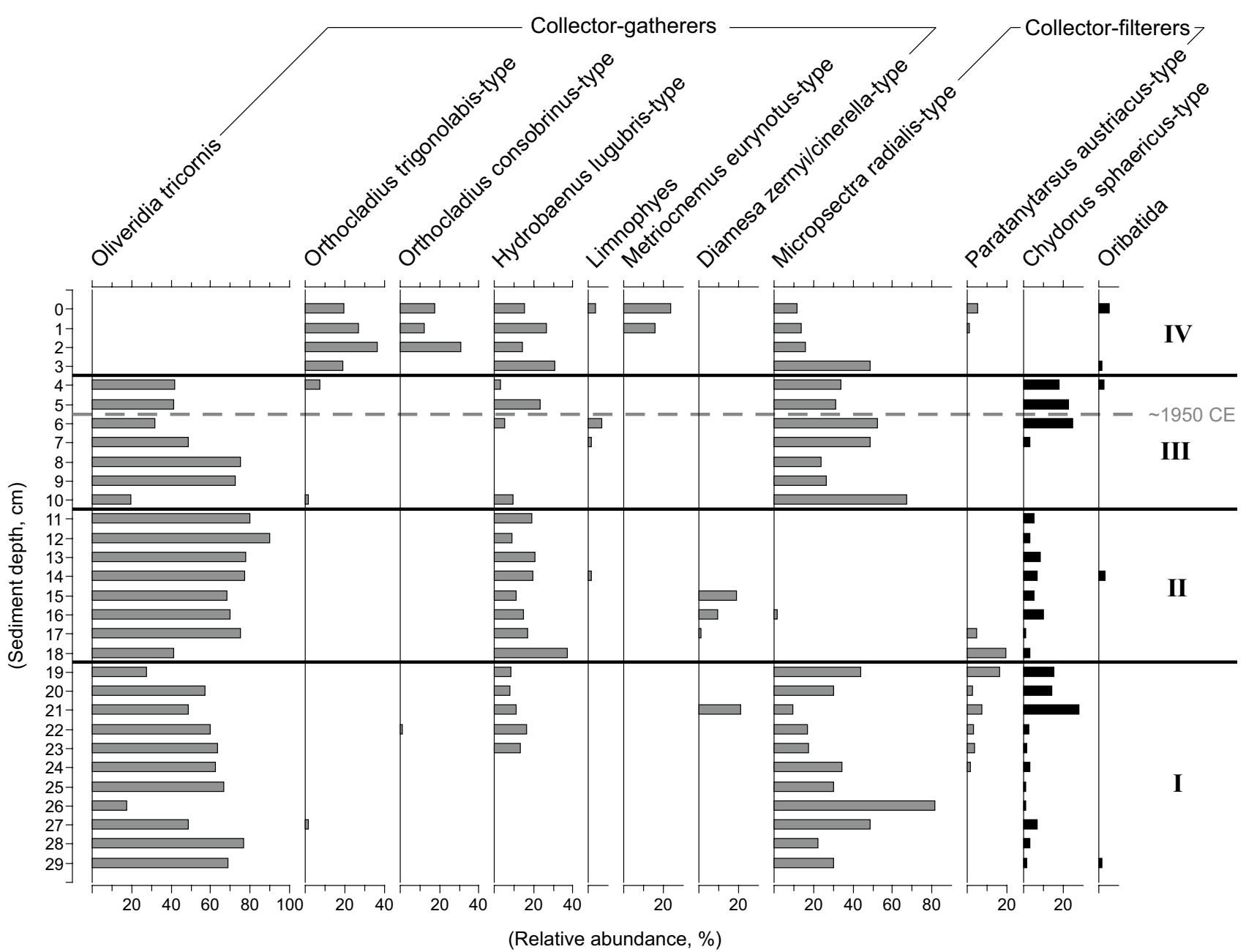

Fig. 5 Chironomid stratigraphy of the most common taxa $(\mathrm{N} \geq 2$, $\min \geq 2$ ) in Revvatnet grouped according to their feeding guilds. The faunal zones (I-IV) were established using cluster analysis and

present at $4 \mathrm{~cm}$ owing to distinct increases in A. minutissimum and Nitzschia spp. The chironomid axis 2 scores were low in the early phase of the stratigraphy $(29-24 \mathrm{~cm})$, after which they increased until a new decrease at $10 \mathrm{~cm}$.

The functional classification of diatoms (Fig. 7) showed that planktonic taxa were abundant in the initial part of the sediment profile, between 28 and $16 \mathrm{~cm}$, followed by a marked decrease that lasted until the present day. In contrast, low profile diatoms had their maximum abundances at the topmost samples between 8 and $0 \mathrm{~cm}$, where high profile diatoms decreased. Motile diatoms were common throughout the stratigraphy but their highest abundances occurred between 14 and $0 \mathrm{~cm}$. Nitzschioids showed a progressively increasing trend from the bottom of the core towards the present, with a significant shift at $\sim 1950 \mathrm{CE}$ when diatom taxonomic diversity (measured as N2) also peaked.

Only two feeding guilds of chironomids were encountered from the stratigraphy (Fig. 8). Collector-gatherers the age horizon (grey dashed line) using ${ }^{137} \mathrm{Cs}$ analysis. The relative abundances of cladoceran Chydrorus sphaericus-type and oribatid mites are calculated from the total sum of invertebrates

were present throughout the core, but collector-filterers were absent from the stratigraphy between 15 and $11 \mathrm{~cm}$. Chironomids indicative of bird presence were absent in the initial phase of the sediment profile but showed moderate abundances ( 10-20\%) between 23 and $10 \mathrm{~cm}$. After a short absence period, bird indicators reappeared at $7 \mathrm{~cm}$ and became highly abundant $(>80 \%)$ in the topmost samples $(2-0 \mathrm{~cm})$, where also the chironomid taxonomic diversity was highest.

Microplastic particles were found in the topmost sediment layers beginning from $2 \mathrm{~cm}(\sim 1990 \mathrm{~s})$ upwards (Fig. 9). The highest microplastic accumulation (7.4 particles $/ \mathrm{cm}^{3}$ ) was enumerated in the surface sample. Size fraction 100-500 $\mu \mathrm{m}$ was the most common in all samples where microplastics were encountered. 


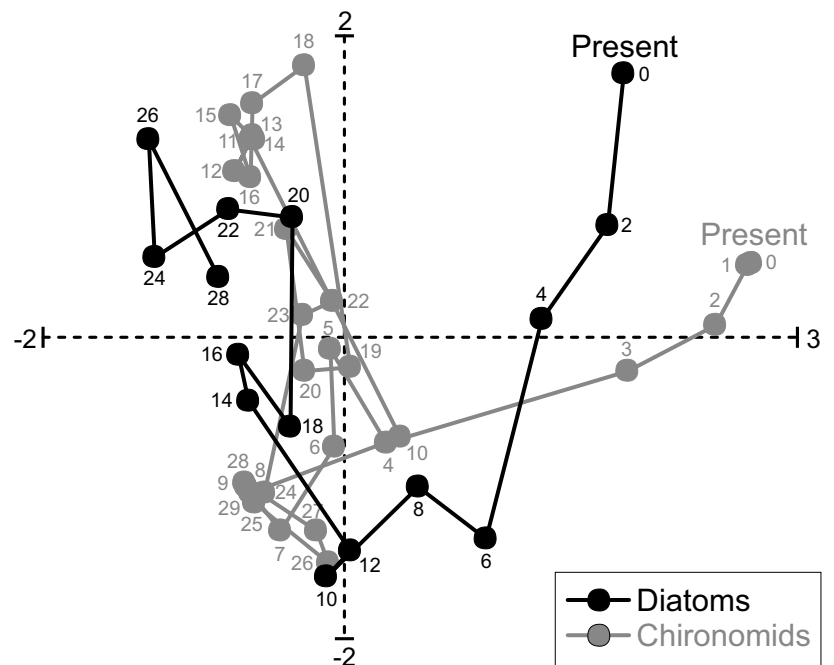

Fig. 6 Principal component analysis axis 1 and 2 scores for diatom (black) and chironomid (grey) samples of the Revvatnet sediment record

\section{Discussion}

\section{Elemental cycling}

Magnetic susceptibility increased in Revvatnet at two stages (Fig. 3), at $18 \mathrm{~cm}$ and at $6 \mathrm{~cm}$, representing roughly the end of the Little Ice Age and the 1950s, respectively. Increases in magnetic mineral content of lake sediments are typically derived from more intense catchment erosion (Thompson et al. 1975; Dearing 1999; Ojala et al.
2017). In High Arctic environment with valley glaciers, magnetic susceptibility can also closely track changes in glacier oscillations through erosional effects (Nesje et al. 2001; Carlson et al. 2017). The recently increased values in Revvatnet correspond with the observed thinning rates in western Svalbard glaciers (Kohler et al. 2007) suggesting increasing melt water discharges (Fig. 1) and causing more intense erosion and transportation of mineral material delivery of melt waters into the Revvatnet basin from the northern inlets. The influence of glacier retreat, which began following the Little Ice Age, is also reflected in the marine sediment records from Hornsund fjord, but as the major glaciers fronts apparently retreated rapidly to the inner bays, the iceberg discharge to the fjord center became quickly limited (Pawłowska et al. 2016). In Lake Revvatnet, previous studies suggest a development towards a more turbid environment (Sienkiewicz et al. 2017). According to a contemporary survey (Ojala et al. 2016), the northern basin of Revvatnet (Fig. 1b) is significantly more turbid (11 formazin turbidity units, FTU) during summer open water season than the southern basin (4 FTU), from where the current core RE2 was collected. There is also a clear difference in the temperatures of the two basins, as the shallower northern basin is $\sim 2{ }^{\circ} \mathrm{C}$ warmer. Despite the distinct difference in turbidity and temperature, no vertical stratification was observed suggesting continuous mixing during the summer. Since the Revvatnet basins are separated by a limnological and bathymetric sill, it inevitably has ecological significance.

The clear decrease in organic matter content at $18 \mathrm{~cm}$ (Fig. 3) is likely more related to increased transport of mineral matter from the catchment, as suggested by the magnetic

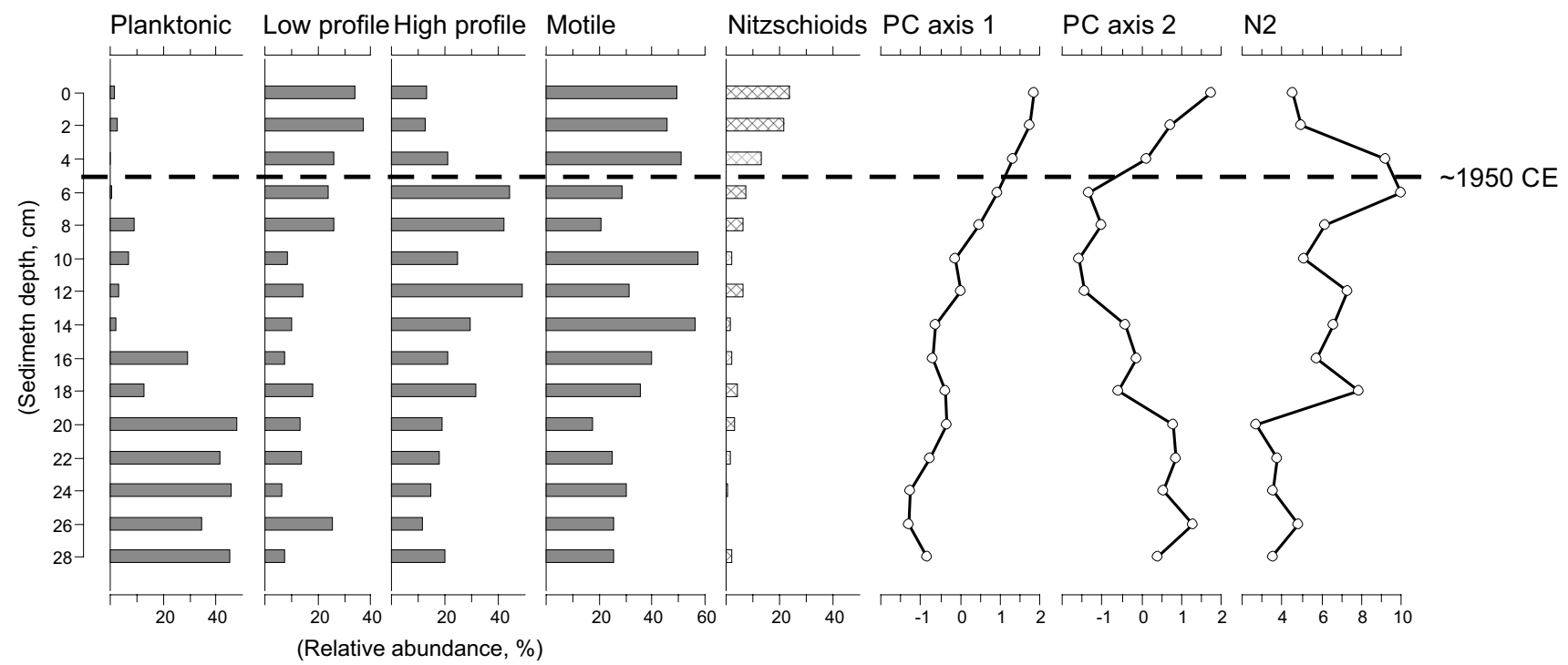

Fig. 7 Ecological guilds (grey) of diatoms (all diatoms included), relative share of nitzchioids (white pattern fill), principal component (PC) axis scores and effective diatom diversity (N2) in Revvatnet. The age horizon established using ${ }^{137} \mathrm{Cs}$ analysis is marked with a dashed line 


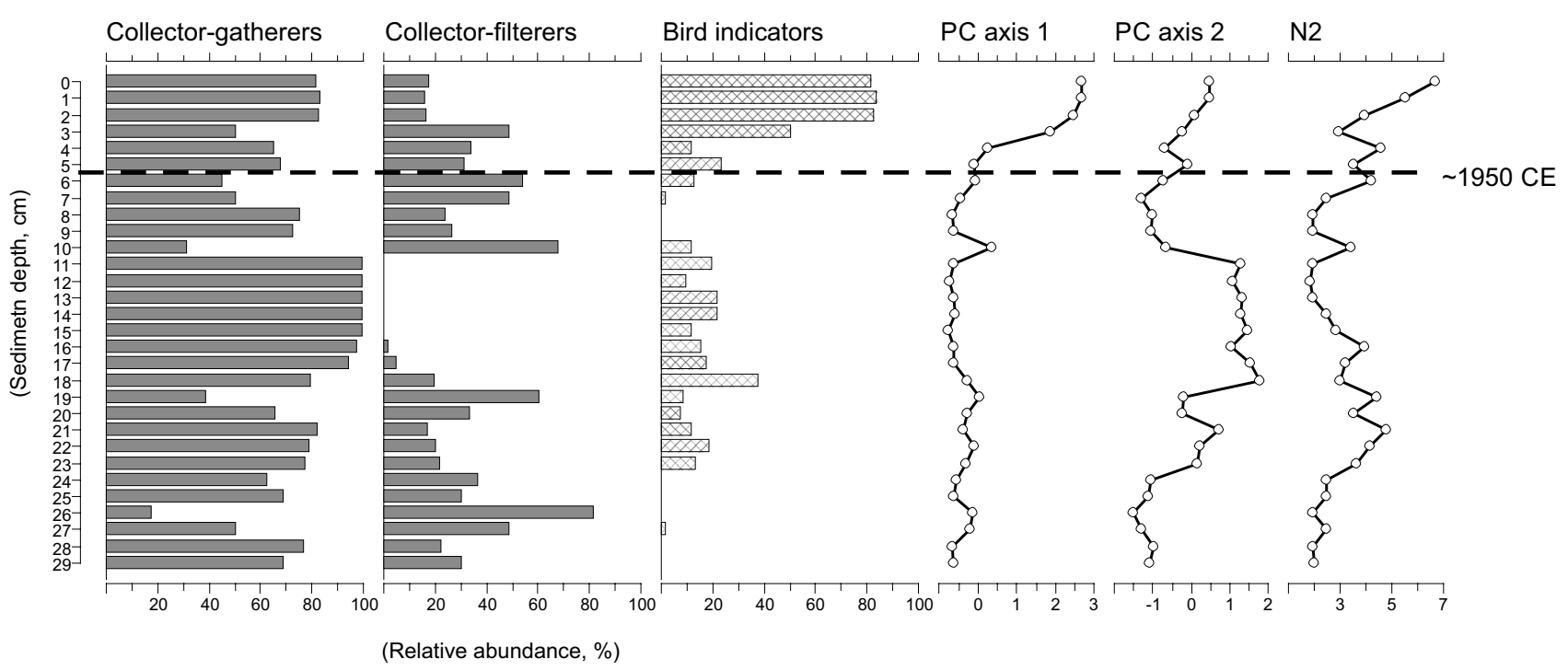

Fig. 8 Feeding guilds (grey) of chironomids (all chironomids included), relative share of taxa indicative of bird-impacted lakes (white pattern fill), principal component (PC) axis scores and effec-

susceptibility values, than a decrease in lake productivity (Meyers and Lallier-Vergès 1999). Nonetheless, this time horizon, corresponding roughly to the end of the Little Ice Age, was also a threshold for increasing $\delta^{13} \mathrm{C}$ and also the total $\mathrm{C}$ and $\mathrm{N}$ contents had step shifts to lower relative values. These geochemical changes were accompanied by shifts in chironomid and diatom PC axis 2 values suggesting a secondary ecological response to the environmental change. The increased $\delta^{13} \mathrm{C}$ values may indicate a change in benthic/ periphytic production, which together with the other evidence, could reflect limnological and catchment processes that were driven by the end of the cold Little Ice Age and intensified melting of the glaciers, increased erosion and longer ice-free period (Guilizzoni et al. 2006). However, the exact timing and the changes in air temperature (D'Andrea et al. 2012) cannot be reliably connected with the current record due to the restrictions of the chronology. Therefore, the climate influence on the biogeochemical changes cannot be resolved from the data, although the majority of the longterm changes in the Arctic are considered climate driven (Smol and Douglas 2007b).

The second stage shift in environmental conditions occurred at $6 \mathrm{~cm}$, corresponding to the mid-twentieth century (Fig. 3). The record high values in magnetic susceptibility during the upper part of the sediment profile and concurrent increase in air temperatures (D'Andrea et al. 2012) suggest further increase in glacier melt water delivery and catchment erosion. This interpretation is supported by the slightly decreased organic matter content. The $\mathrm{C}_{\text {org }} / \mathrm{N}_{\text {tot }}$ ratio showed a decreasing trend from the mid-twentieth century to the present indicating that productivity in Revvatnet shifted tive chironomid diversity (N2) in Revvatnet. The age horizon established using ${ }^{137} \mathrm{Cs}$ analysis is marked with a dashed line

from presumably mixed allochthonous and autochthonous to strictly autochthonous. A similar $\mathrm{C}_{\text {org }} / \mathrm{N}_{\text {tot }}$ shift has also been recorded from the adjacent geese-impacted pond Fugledammen (Luoto et al. 2015). Geese are present also in the catchment of Revvatnet, but Little Auks are particularly abundant (nesting cliff) fertilizing local tundra with their excrement through extensive transport of nutrients from the marine to terrestrial environment (Moe et al. 2009; Gąsiorowski and Sienkiewicz 2019). In addition to lowering $\mathrm{C}_{\text {org }} / \mathrm{N}_{\text {tot }}$ ratio, heavier $\delta^{15} \mathrm{~N}$ signature has been shown to be closely connected with seabird affected Arctic lakes (Griffiths et al. 2010; Stewart et al. 2013; Hargan et al. 2017). In Revvatnet, the $\delta^{15} \mathrm{~N}$ signal is rather variable during the latter half of the sediment profile compared to the earlier parts, but shows mostly ${ }^{15} \mathrm{~N}$-enriched values since the mid-twentieth century with initial peak already during the early twentieth century. Compared to $\delta^{15} \mathrm{~N}$ values measured from profundal lake sediments from Little Auk impacted sites in Greenland ( 20\%o) (González-Bergonzoni et al. 2017), the values in Revvatnet (3.4\% in the surface sediment) remain rather low (Fig. 8), probably owing to its short residence time and smaller size of the colonies.

\section{Ecological shifts}

The diatom record in Revvatnet showed both gradual directional shifts and abrupt turnovers (Fig. 4). The most striking change was the sudden decrease in the centric Cyclotella rossii-comensis-tripartita complex, which dominated the diatom community during the early half of the stratigraphy (zone I). Although cosmopolitan by 

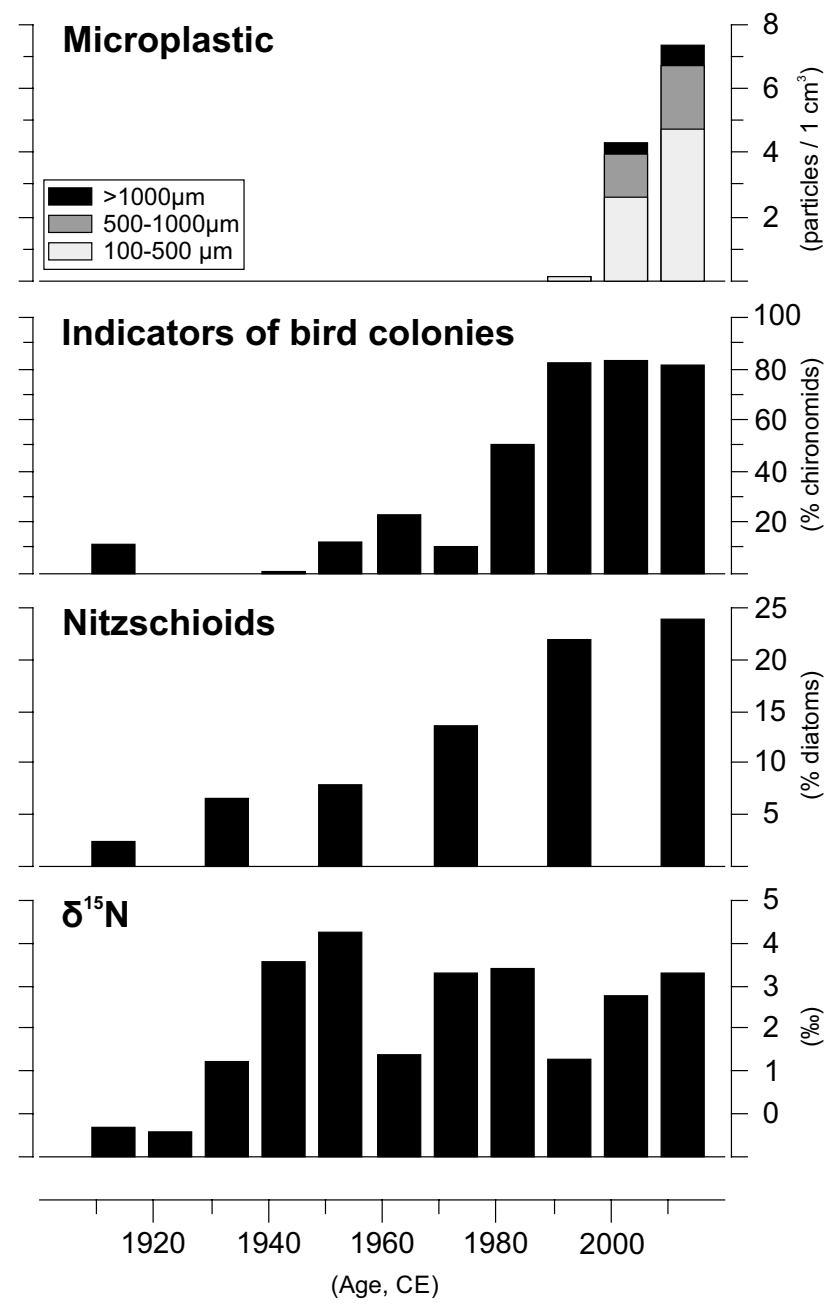

Fig. 9 Accumulation of microplastic particles with different size fractions in Revvatnet compared with indicators (chironomids, nitzschioid diatoms and $\delta^{15} \mathrm{~N}$ ) of seabird colonies (biovector)

nature, this species complex has been found a dominant component in the clear, oligotrophic lakes in East Greenland (Cremer and Wagner 2004) and indicates stability of surrounding Arctic landscape (Perren et al. 2012). Small cyclotelloids are generally considered sensitive to changes in water clarity and physical structure of the water column, while changing nutrient regimes may also govern their abundance (Rühland et al. 2015; Saros and Anderson 2015). While the $C$. rossii-comensis-tripartita complex rapidly decreased at $14 \mathrm{~cm}$ (zone II) and finally disappeared at $4 \mathrm{~cm}$ (zone IV), Achnanthidium minutissimum, a benthic pennate species, increased towards the present, especially from $8 \mathrm{~cm}$ (zone III) onward. In warmer climates A. minutissimum is known as a primary colonizer in disturbed environments with turbid waters and watersheds characterized by loss in vegetation cover (Peterson and Stevenson 1992; Caballero et al. 2006). Therefore, these shifts in the diatom community of Revvatnet may indicate a transition from a clear and oligotrophic lake toward a more turbid environment with diminished light penetration.

In all, the diatom assemblages in Revvatnet appear to be more responsive to catchment disturbances and prolonged delivery of suspended fine-grained mineral matter rather than climate warming directly. An increase of magnetic susceptibility in upper sediment agrees well with this observation (Fig. 3). However, the distinct decrease in Pseudostaurosira brevistriata at $4 \mathrm{~cm}$ (zone IV), representing the 1960s, can be linked with climate change, as the species has been observed to decline in cold, oligotrophic, deep lakes with extensive ice cover due to recent climate warming (Rühland et al. 2003). Also the increase in A. minutissimum has been related to climate warming in several Arctic records (Antoniades et al. 2004; Keatley et al. 2006; Lim et al. 2008; Paul et al. 2010), but it is also found in mossy habitats (Griffiths et al. 2017) suggesting that the lake-catchment area has become more productive. The recent increase in Nitzschia spp. is also likely related to increase in nutrients, as previously recorded from the Canadian Arctic (Michelutti et al. 2007). In all, the recent changes in diatom assemblages are likely related directly (e.g. longer ice-free period) or indirectly (increased turbidity and nutrients) to climate change.

Chironomids respond primarily to air or water temperature (Eggermont and Heiri 2012), but the taxonomic composition of Revvatnet consists thoroughly of taxa with the coldest temperature optima (Heiri et al. 2011). This is not surprising, since the study lake is situated in the High Arctic and is fed by glaciers. The chironomid fauna resembles that found in Einstaken (Luoto et al. 2011), a lake located in northernmost Svalbard $\left(80^{\circ} \mathrm{N}\right)$ with a mean July air temperature of only $\sim 2{ }^{\circ} \mathrm{C}$. However, compared to an adjacent $(15 \mathrm{~km})$ lake Svartvatnet, located on the southern side of the Hornsund fjord, the chironomid compositions differ despite the similar deep oligotrophic character of the two lakes. For example, Micropsectra contracta-type, which has dominated in Svartvatnet for at least the last 5000 years (Luoto et al. 2018), is completely absent in the Revvatnet record (Fig. 5). Since $M$. contracta-type has a warmer temperature preference (Heiri et al. 2011) than the taxa encountered in Revvatnet, it is likely that its absence from the present record is caused by a continuous production-season inflow of cold water (glacial melting influence), which is not a factor in Svartvatnet.

The greatest shifts in the chironomid communities in the RE2 record occur when $M$. radialis-type disappears between 18 and $11 \mathrm{~cm}$ (zone II) and when Oliveridia tricornis vanish from the stratigraphy at $3 \mathrm{~cm}$ (zone IV) (Fig. 5). In Einstaken, decrease in M. radialis-type was related to climate warming (Luoto et al. 2011), but this is not the case in Revvatnet since its absence occurs when the temperatures were still very low following the Little Ice 
Age (D'Andrea et al. 2012), and furthermore, it reappeared when the climate warmed during the twentieth century. Since the timing when $M$. radialis-type disappeared coincides roughly with changes in diatoms and when Cyclotella rossii-comensis-tripartita complex began to decrease (Fig. 4), it may be that it is related to changes in minerogenic water turbidity. Nonetheless, since the changes in chironomids and diatoms were not fully synchronous at this time, it may also be that $M$. radialis-type was responding to reduced hypolimnetic oxygen conditions caused by the increased turbidity and subsequent potential vertical stratification. While it is possible that the study lake thermally stratified in the past (at the end of the Little Ice Age) by enhanced glacial input, cold glacial meltwater may also have disrupted the thermal stratification of the water column when climate began to warm in the twentieth century, thereby altering the diatom (i.e. shift from planktonic to benthic) and chironomid assemblages (i.e. shift in the oxy-stressor $M$. radialis-type). This interpretation would be similar to a previous diatom study from Revvatnet (Sienkiewicz et al. 2017). Also the extirpation of $O$. tricornis can be related to changes in water quality, because it corresponds with the sample where also the only cladoceran in the record, Chydorus sphaericustype, disappears. In another site located in Hornsund, Fugledammen, the decrease in C. sphaericus-type towards the present was linked with increased nutrient conditions that turned the pond murky (Luoto et al. 2015). Therefore, the chironomid and cladoceran shift at $3 \mathrm{~cm}$ can also be related to limno-optical changes in the lake environment. These changes were likely catchment originated, as indicated by the appearance of Metriocnemus eurynotus-type, which is a semiterrestrial taxon (Brooks et al. 2007), suggesting material transport from the watershed. Nonetheless, similar to the recent increase in Nitzshia spp. (Fig. 4), the chironomid zone I is characterized by appearance of Orthocladius species that also clearly indicate increased trophic state (Brooks and Birks 2004).

The algal and invertebrate communities, representing primary and secondary producers, have generally parallel community dynamics in Revvatnet (Figs. 4, 5), which is also shown by the ordination results suggesting a shift that is directionally similar (Fig. 6). Interestingly, both ordinations clearly separate the recent samples into their own primary axis cluster showing that the communities of the recent decades are unprecedented compared to the earlier biostratigraphy. This finding supports previous evidence that significant changes in Arctic aquatic communities are currently occurring, and that critical ecological thresholds are being crossed (Smol and Douglas 2007a, b; Axford et al. 2009). The current taxonomic records also suggest that the climate influence may not always be direct but the recent changes may also occur due to indirect climate influence, i.e. increase in the bird colony, hence suggesting multiple community responses (Smol 2010).

In addition to taxonomic compositions, applications of functional characteristics of aquatic organisms can be valuable for understanding ecosystem processes and dynamics (Jeppesen et al. 2001; Nevalainen and Luoto 2017; Kivilä et al. 2019). In Revvatnet, the changes in diatom ecological guilds support the environmental evidence derived from taxonomic compositions. A decrease in planktonic diatoms at the core depth of $14 \mathrm{~cm}$ and increases in low profile (such as achnanthoids) as well as motile (such as nitzschioids and naviculoids) life forms (Fig. 7), which include diatoms that typically tolerate physical disturbances (Tapolczai et al. 2016), provide uniform evidence for increased water turbidity. Only two chironomid feeding guilds were encountered in the Revvatnet sediment profile (Fig. 8), which hampers more detailed interpretation.

As birds nesting or grazing in tundra are known to influence Arctic lakes (Mariash et al. 2018), we separated diatom and chironomid taxa that are typically associated with lakes that have significant bird populations in their catchment (e.g. Brooks and Birks 2004; Jones and Birks 2004). As a result, nitzschioid diatoms and chironomid bird indicators both showed an increasing trend from $\sim 24 \mathrm{~cm}$ onward with largest shifts during the most recent decades (Figs. 7, 8). In the previous study from the neighboring pond Fugledammen located in the Fuglebergsletta (Fig. 1c), it was shown that the impact of Barnacle geese significantly increased during the twentieth century (Luoto et al. 2015). Similar evidence of geese population growth has also been found from northeastern Svalbard (Luoto et al. 2014). A study of peat sequences from the current study areas also suggested major Little Auk population growth, with a threshold occurring at 1920 CE (Gąsiorowski and Sienkiewicz 2019). Therefore, it appears to be clear that the bird impact has become a significant factor in Svalbard over the past decades, consequently altering the aquatic ecosystems and watersheds. The response of diatoms to nutrients can be direct but in case of chironomids the bird impact may derive from deteriorated oxygen conditions (Stewart et al. 2013). However, there are no signs of current summertime vertical stratification in Revvatnet (Ojala et al. 2016), reducing the likelyhood that oxygen decrease is driving the increase in the bird indicator taxa. In addition, the presence of Micropsectra suggests well-oxygenated hypolimnion, since it is an "oxy-stressor", a genus that requires high oxygen levels (Brodersen et al. 2008). An option is that the chironomid response is due to habitat change, since the bird indicators $O$. trigonolabistype and $O$. consobrinus-type prefer more productive lakes in Svalbard with aquatic macrophytes present (Brooks and Birks 2004; Luoto et al. 2016). An unpublished analysis of a sediment core from the northern basin (RE8 in Ojala et al. 2016) showed that while other invertebrate remains were 
very scarce, ostracods (Podocopida) were numerous, unlike in the southern basin where they were completely absent. Previous studies from Hornsund (Luoto et al. 2015) and elsewhere in Svalbard (Luoto et al. 2014) have shown that ostracods increase under a bird-induced eutrophication process and they are more common in contemporary samples of moderately impacted (nutrient-rich) lakes of Fuglebergsletta with dense macrophyte growth (Luoto et al. 2016), hence supporting the interpretation on habitat change.

There are also major changes in taxonomic diversity in the RE2 record during the recent decades. In diatoms, the diversity increased until $\sim 1950 \mathrm{~s}$ but then rapidly decreased (Fig. 7). Chironomid diversity also increased towards the 1950 s, but unlike with diatoms, it remained elevated and further increased during the most recent decades (Fig. 8). The recent decline in diatom diversity is likely caused by the increased turbidity restricting many planktonic and pennate diatoms (Bradshaw et al. 2000). In fact, it has been shown that concurrently increasing water turbidity and nutrient levels can cause decline in planktonic and benthic diatom diversities, while chironomid diversity simultaneously increased (Luoto et al. 2017) supporting the interpretation of turbidity and nutrient control on the recent ecosystem changes in Revvatnet.

\section{Microplastic delivery}

A scan for microplastic accumulation in the Revvatnet RE2 sediments revealed that the first encountered particles appeared at $2 \mathrm{~cm}$ depth, representing the 1990s, with an increasing abundance towards the present (Fig. 9). Microplastics are harmful for freshwater organisms, especially since their bioaccumulation potential increases with decreasing size (Lee et al. 2013). In the Revvatnet sediment, the most common particle size was the smallest analyzed size fraction $(100-500 \mu \mathrm{m})$ that is potentially most harmful for chironomids, since they can swallow these sized particles with their mouthparts, but have great risk of causing an obstruction (Scherer et al. 2017). In the samples, where microplastics were found, collector-filterers decreased (Fig. 4), which might suggest a causal relationship. Also the fine-mesh filter-feeding cladoceran Chydorus sphaericustype disappeared from the topmost samples, this change possibly being related to microplastic fragment consumption. However, since microplastic occurrences are represented only in three uppermost and most recently deposited sediment samples $(2-0 \mathrm{~cm})$ and no ecotoxicological experiments have been performed, these interpretations remain merely speculative.

Though mostly investigated in marine environments, microplastics are also transported to Arctic lakes directly by humans or via the atmosphere and biovectors, such as seabirds (Wagner et al. 2014), which feed in the ocean (ingestion) and defecate in their terrestrial nesting grounds. Significant amounts of microplastic have been found in several arctic seabirds, including Little Auks (O'Hanlon et al. 2017). In fact, Little Auks, which are abundant in the catchment of Revvatnet, are particularly susceptible to ingesting microplastic, since they predominantly feed on smaller prey items (such as copepods) and therefore are more likely to mistake microplastic for prey, or ingest it accidentally whilst foraging (Amélineau et al. 2016). In the current record, the chironomid-, diatom- and $\delta^{15} \mathrm{~N}$-inferred increase in Little Auk colonies initiate just before the appearance of microplastics (Fig. 9) indicating availability of an efficient biovector for marine derived contaminants. In addition to the physiological damaging effects resulting from direct ingestion of microplastics by aquatic organisms, microplastics also act as vectors for organic pollutants (e.g. other POPs) (Bakir et al. 2014). Although this prospective study cannot resolve the response of aquatic taxa to microplastic pollution, our findings suggest high probability for Arctic freshwater biota to encounter microplastics and a potential for trophic interactions and functional changes. However, further research is required to understand the particle transport and effects of microplastic-biota interactions within increasingly productive High Arctic freshwater environments.

\section{Conclusions}

The present study showed major changes in the physical, biogeochemical and ecological environment of the High Arctic Revvatnet and its catchment. The environmental changes occurred at two stages during the end of the Little Ice Age and the mid-twentieth century. Our results suggest progressively increasing transport of mineral matter from the catchment that originated from glacial melt water erosion, and subsequently caused significantly more turbid waters in Revvatnet. We recorded increased biogeochemical cycling also through a more productive catchment and higher lake autochthony. Based on the increase in nitzschioid diatoms, bird indicating chironomids and decline in the $\mathrm{C}_{\text {org }} / \mathrm{N}_{\text {tot }}$ ratio, for example, the influence of expanding Little Auk colonies in the catchment was noticeable but superimposed with the other climate warming impacts on Revvatnet. The increased Little Auk population has also produced a pathway for microplastic delivery, as we reported microplastic particles in the sediments since the 1990s with a progressive accumulation rate. Overall, we recorded multiple ecological responses and functional shifts of the aquatic ecosystem, whilst the influences of climate change as the ultimate driving force are undisputable.

As also demonstrated by the current study, climateforced changes cause cascading effects on the terrestrial and aquatic environments in the Arctic, with increased glacier 
melt and erosion, more productive catchments and limnologically altered freshwater basins. Based on the present results, it becomes clear that the patterns in biogeochemical elemental cycling have changed with significant thresholds being crossed. The driving forces of the major changes of Arctic lakes are evidently anthropogenic through humaninduced climate warming and delivery of pollutants.

Acknowledgements Open access funding provided by University of Helsinki including Helsinki University Central Hospital. Financial support for the study was proved by the Kone Foundation [T. P. Luoto, Grant\# 090140], Emil Aaltonen Foundation [T.P. Luoto, Grants\# 160156, 170161 and 180151] and Academy of Finland [A.E.K. Ojala, Grant\# 259343; L. Nevalainen, Grant\# 308954, M.V. Rantala, Grant\# 314107]. We thank Laura Arppe, Mimmi Oksman, Marek Zajączkowski, Mateusz Damrat, Joanna Pawłowska and the crew of the Polish Polar Station Hornsund for their help with the fieldwork and logistical support. We are grateful for the two journal reviewers for constructive comments that helped to improve the quality and value of the manuscript.

Open Access This article is distributed under the terms of the Creative Commons Attribution 4.0 International License (http://creativeco mmons.org/licenses/by/4.0/), which permits unrestricted use, distribution, and reproduction in any medium, provided you give appropriate credit to the original author(s) and the source, provide a link to the Creative Commons license, and indicate if changes were made.

\section{References}

Amélineau F, Bonnet D, Heitz O, Mortreux V, Harding AMA, Karnovsky N, Walkusz W, Fort J, Grémillet D (2016) Microplastic pollution in the Greenland Sea: background levels and selective contamination of planktivorous diving seabirds. Environ Pollut 219:1131-1139

Antoniades D, Douglas MSV, Smol JP (2004) Diatom species-environment relationships and inference models from Isachsen, EllefRingnes Island, Canadian High Arctic. Hydrobiologia 529:1-18

Appleby PG (2004) Environmental change and atmospheric contamination on Svalbard: sediment chronology. J Paleolimnol 31:433-443

Axford Y, Briner JP, Cooke CA, Francis DR, Michelutti N, Miller GH, Smol JP, Thomas EK, Wilson R, Wolfe AP (2009) Recent changes in a remote Arctic lake are unique within the past 200,000 years. Proc Natl Acad Sci 160:18443-18446

Bakir A, Rowland SJ, Thompson RC (2014) Transport of persistent organic pollutants by microplastics in estuarine conditions. Estuar Coast Shelf Sci 140:14-21

Battarbee RW, Jones VJ, Flower RJ, Cameron NC, Bennion H, Carvalho L, Juggins S (2001) Diatoms. In: Smol JP, Birks HJB, Last WM (eds) Tracking environmental change using lake sediments, terrestrial, algal, and siliceous indicators, vol 3. Kluwer Academic Publishers, Dordrecht, pp 155-202

Bouchard F, Turner KW, MacDonald LA, Deakin C, White H, Farquharson N, Medeiros AS, Wolfe BB, Hall RI, Pienitz R, Edwards TWD (2013) Vulnerability of shallow subarctic lakes to evaporate and desiccate when snowmelt runoff is low. Geophys Res Lett 40:6112-6117

Bradshaw EG, Jones VJ, Birks HJB, Birks HH (2000) Diatom responses to late-glacial and early-Holocene environmental changes at Kråkenes, western Norway. J Paleolimnol 23:21-34
Brodersen KP, Pedersen O, Walker IR, Jensen MT (2008) Respiration of midges (Diptera; Chironomidae) in British Columbian lakes: oxy-regulation, temperature and their role as palaeo-indicators. Freshw Biol 53:593-602

Brooks SJ, Birks HJB (2004) The dynamics of Chironomidae (Insecta: Diptera) assemblages in response to environmental change during the past 700 years on Svalbard. J Paleolimnol 31:483-498

Brooks SJ, Langdon PG, Heiri O (2007) The identification and use of Palaearctic Chironomidae larvae in palaeoecology. Quaternary Research Association, London, p 276

Caballero M, Vázquez G, Lozano-García S, Rodríguez A, Sosa-Nájera S, Ruiz-Fernández AC, Ortega B (2006) Present limnological conditions and recent (ca. 340 year) palaeolimnology of a tropical lake in the Sierra de Los Tuxtlas, Eastern Mexico. J Paleolimnol 35:83-97

Carlson AE, Kilmer Z, Ziegler LB, Stoner JS, Wiles GC, Starr K, Walczak MH, Colgan W, Reyes AV, Leydet DJ, Hatfield RG (2017) Recent retreat of Columbia Glacier, Alaska: Millennial context. Geology 45:547-550

Chu SQ, Liu GQ, Gao JQ, Yi D (2006) A 150-year record of heavy metals in the varved sediments of Lake Bolterskardet, Svalbard. Arc Antarct Alp Res 38:436-445

Cole M, Lindeque P, Halsband C, Galloway TS (2011) Microplastics as contaminants in the marine environment: a review. Mar Pollut Bull 62:2588-2597

Côté G, Pienitz R, Velle G, Wang X (2010) Impact of geese on the limnology of lakes and ponds from Bylot Island (Nunavut, Canada). Int Rev Hydrobiol 95:105-129

Cremer H, Wagner B (2004) Planktonic diatom communities in High Arctic lakes (Store Koldewey, Northeast Greenland). Can J Bot 82:1744-1757

D'Andrea WJ, Vaillencourt DA, Balascio NL, Werner A, Roof SR, Retelle M, Bradley RS (2012) Mild Little Ice Age and unprecedented recent warmth in an 1800 years lake sediment record from Svalbard. Geology 40:1007-1010

Dean WE (1974) Determination of carbonate and organic matter in calcareous sediments and sedimentary rocks by loss on ignition: comparison with other methods. J Sediment Petrol 44:242-258

Dearing J (1999) Magnetic susceptibility. In: J Walden, F Oldfield, J Smith (eds) Environmental magnetism: a practical guide. Technical guide. No. 6. Quaternary Research Association, London, pp 35-62

Dris R, Imhof H, Sanchez W, Gasperi J, Galgani F, Tassin B, Laforsch C (2015) Beyond the ocean: contamination of freshwater ecosystems with (micro-) plastic particles. Environ Chem 12:539-550

Eerkes-Medrano D, Thompson RC, Aldridge DC (2015) Microplastics in freshwater systems: a review of the emerging threats, identification of knowledge gaps and prioritisation of research needs. Water Res 75:63-82

Eggermont H, Heiri O (2012) The chironomid-temperature relationship: expression in nature and palaeoenvironmental implications. Biol Rev 87:430-456

Engels S, Self AE, Luoto TP, Brooks SJ, Helmens KF (2014) A comparison of three Eurasian chironomid-climate calibration datasets on a W-E continentality gradient and the implications for quantitative temperature reconstructions. J Paleolimnol 51:529-547

Forbes BC, Fauria MM, Zetterberg P (2010) Russian Arctic warming and 'greening' are closely tracked by tundra shrub willows. Glob Change Biol 16:1542-1554

Gąsiorowski M, Sienkiewicz E (2019) Bird population changes reconstructed from isotopic signals of peat developed in a nutrient enriched tundra. Sci Total Environ 646:1359-1366

González-Bergonzoni I, Johansen KL, Mosbech A, Landkildehus F, Jeppesen E, Davidson TA (2017) Small birds, big effects: the little auk (Alle alle) transforms high Arctic ecosystems. Proc R Soc B 284:20162572 
Griffiths K, Michelutti N, Blais JM, Kimpe LE, Smol JP (2010) Comparing nitrogen isotopic signals between bulk sediments and invertebrate remains in High Arctic seabird-influenced ponds. J Paleolimnol 44:405-412

Griffiths K, Michelutti N, Sugar M, Douglas MSV, Smol JP (2017) Icecover is the principal driver of ecological change in High Arctic lakes and ponds. PloS One 12:e172989

Guilizzoni P, Marchetto A, Lami A, Brauer A, Vigliotti L, Musazzi S, Langone L, Manca M, Lucchini F, Calanchi N, Dinelli E, Mordenti A (2006) Records of environmental and climatic changes during the late Holocene from Svalbard: palaeolimnology of Kongressvatnet. J Paleolimnol 36:325-351

Hammer Ø, Harper DAT, Ryan PD (2001) PAST: paleontological statistics software package for education and data analysis. Palaeontol Electron 4:9

Hargan KE, Michelutti N, Coleman K, Grooms C, Blais JM, Kimpe LE, Gilchrist G, Mallory M, Smol JP (2017) Cliff-nesting seabirds influence production and sediment chemistry of lakes situated above their colony. Sci Total Environ 576:85-98

Heiri O, Lotter AF (2001) Effect of low count sums on quantitative environmental reconstructions: an example using subfossil chironomids. J Paleolimnol 26:343-350

Heiri O, Brooks SJ, Birks HJB, Lotter AF (2011) A 274-lake calibration data-set and inference model for chironomid-based summer air temperature reconstruction in Europe. Quat Sci Rev 30:3445-3456

Hill MO (1973) Diversity and evenness: a unifying notation and its consequences. Ecology 54:427-432

Hobbie JE, Peterson BJ, Bettez N, Deegan L, O'Brien WJ, Kling GW, Kipphut GW, Bowden WB, Hershey AE (1999) Impact of global change on the biogeochemistry and ecology of an Arctic freshwater system. Polar Res 18:207-214

Holmgren SU, Bigler C, Ingólfsson O, Wolfe AP (2010) The Holocene-Anthropocene transition in lakes of western Spitsbergen, Svalbard (Norwegian High Arctic): climate change and nitrogen deposition. J Paleolimnol 43:393-412

Horton AA, Walton A, Spurgeon DJ, Lahive E, Svendsen C (2017) Microplastics in freshwater and terrestrial environments: evaluating the current understanding to identify the knowledge gaps and future research priorities. Sci Total Environ 586:127-141

Jeppesen E, Leavitt P, De Meester L, Jensen JP (2001) Functional ecology and palaeolimnology: using cladoceran remains to reconstruct anthropogenic impact. Trends Ecol Evol 16:191-198

Jeppesen E, Nõges P, Davidson TA et al (2011) Zooplankton as indicators in lakes: a scientific-based plea for including zooplankton in the ecological quality assessment of lakes according to the European Water Framework Directive (WFD). Hydrobiologia 676:279

Jones VJ, Birks HJB (2004) Lake-sediment records of recent environmental change on Svalbard: results of diatom analysis. J Paleolimnol 31:445-466

Karczewski A, Kostrzewski A, Marks L (1981) Late Holocene glacier advances in Revdalen, Spitsbergen. Pol Polar Res 2:51-61

Karlsson TM, Vethaak AD, Almroth BC, Ariese F, van Velzen M, Hassellöv M, Leslie HA (2017) Screening for microplastics in sediment, water, marine invertebrates and fish: method development and microplastic accumulation. Mar Pollut Bull 122:403-408

Keatley BE, Douglas MSV, Smol JP (2006) Early-20th century environmental changes inferred using subfossil diatoms from a small pond on Melville Island, N.W.T., Canadian high Arctic. Hydrobiologia 553:15-26

Keatley BE, Douglas MS, Blais JM, Mallory ML, Smol JP (2009) Impacts of seabird-derived nutrients on water quality and diatom assemblages from Cape Vera, Devon Island, Canadian High Arctic. Hydrobiologia 621:191-205
Kivilä EH, Luoto TP, Rantala MV, Rautio M, Kiljunen M, Nevalainen L (2019) Environmental controls on benthic food web functions and carbon resource use in subarctic lakes. Freshw Biol. https:// doi.org/10.1111/fwb.13250

Kohler J, James TD, Murray T, Nuth C, Brandt O, Barrand NE, Aas HF, Luckman A (2007) Acceleration in thinning rate on western Svalbard glaciers. Geophys Res Lett 34:18

Krammer K, Lange-Bertalot H (1986) Bacillariophyceae. 1. Teil: naviculaceae. In: Ettl H, Gerloff J, Heynig H, Mollenhauer D (eds) Süsswasserflora von Mitteleuropa. Band 2/1. Gustav Fischer Verlag, Stuttgart, p 875

Krammer K, Lange-Bertalot H (1988) Bacillariophyceae. 2. Teil: Bacillariaceae, Epithemiaceae, Surirellaceae. In: Ettl H, Gerloff J, Heynig H, Mollenhauer D (eds) Süsswasserflora von Mitteleuropa. Band 2/2. Gustav Fischer Verlag, Stuttgart, p 596

Krammer K, Lange-Bertalot H (1991a) Bacillariophyceae. 3. Teil: Centrales, Fragilariaceae, Eunotiaceae. In: Ettl H, Gerloff J, Heynig H, Mollenhauer D (eds) Süsswasserflora von Mitteleuropa. Band $2 / 3$. Gustav Fischer Verlag, Stuttgart, p 576

Krammer K, Lange-Bertalot H (1991b) Bacillariophyceae. 4. Teil: Achnanthaceae, Kritische, Ergänzungen zu Navicula (Lineolatae) und Gomphonema, Gesamtliteraturverzeichnis. In: Ettl H, Gärtner G, Gerlof J, Heynig H, Mollenhauer D (eds) Süsswasserflora von Mitteleuropa. Band 2/4. Gustav Fischer Verlag, Stuttgart, p 437

Larocque I (2001) How many chironomid head capsules are enough? A statistical approach to determine sample size for palaeoclimatic reconstructions. Palaeogeogr Palaeoclimatol Palaeoecol 172:133-142

Lee KW, Shim WJ, Kwon OY, Kang JH (2013) Size-dependent effects of micro polystyrene particles in the marine copepod Tigriopus japonicus. Environ Sci Technol 47:11278-11283

Lim DSS, Smol JP, Douglas MSV (2008) Recent environmental changes on Banks Island (N.W.T. Canadian Arctic) quantified using diatom assemblages. J Paleolimnol 40:385-398

Linderholm HW, Nicolle M, Francus P et al (2018) Arctic hydroclimate variability during the last 2000 years: current understanding and research challenges. Clim Past 14:473-514

Löder MGJ, Gerdts G (2015) Methodology used for the detection and identification of microplastics - a critical appraisal. In: Bergmann M, Gutow L, Klages M (eds) Marine anthropogenic litter. Springer, Cham, pp 201-227

Luoto TP, Ojala AEK (2018) Controls of climate, catchment erosion and biological production on long-term community and functional changes of chironomids in High Arctic lakes (Svalbard). Palaeogeogr Palaeoclimatol Palaeoecol 505:63-72

Luoto TP, Nevalainen L, Kubischta F, Kultti S, Knudsen KL, Salonen VP (2011) Late Quaternary ecological turnover in high arctic Lake Einstaken, Nordaustlandet, Svalbard $\left(80^{\circ} \mathrm{N}\right)$. Geogr Ann A 93:337-354

Luoto TP, Salonen VP, Larocque-Tobler I, Pienitz R, Hausmann S, Guyard H, St-Onge G (2013) Pro- and postglacial invertebrate communities of Pingualuit Crater Lake, Nunavik (Canada), and their paleoenvironmental implications. Freshw Sci 32:951-963

Luoto TP, Brooks SJ, Salonen VP (2014) Ecological responses to climate change in a bird-impacted High Arctic pond (Nordaustlandet, Svalbard). J Paleolimnol 51:87-97

Luoto TP, Oksman M, Ojala AEK (2015) Climate change and bird impact as drivers of High Arctic pond deterioration. Polar Biol 38:357-368

Luoto TP, Oksman M, Ojala AEK (2016) Invertebrate communities of the High Arctic ponds in Hornsund. Pol Polar Res 37:105-119

Luoto TP, Rantala MV, Tammelin MH (2017) Tracking the limnoecological history of Lake Hiidenvesi (southern Finland) using the paleolimnological approach. Water Air Soil Pollut 228:461 
Luoto TP, Ojala AEK, Arppe L, Brooks SJ, Kurki E, Oksman M, Wooller MJ, Zajączkowski M (2018) Synchronized proxy-based temperature reconstructions reveal mid- to late Holocene climate oscillations in High Arctic Svalbard. J Quat Sci 33:93-99

Luoto TP, Rantala MV, Kivilä EH, Nevalainen L (2019) Recent changes in chironomid communities and hypolimnetic oxygen conditions relate to organic carbon in subarctic ecotonal lakes. Sci Total Environ 646:238-244

Lusher AL, Tirelli V, O'Connor I, Officer R (2015) Microplastics in Arctic polar waters: the first reported values of particles in surface and sub-surface samples. Sci Rep 5:14947

Mandaville SM (2002) Benthic macroinvertebrates in freshwaterstaxa tolerance values, metrics, and protocols. In: Soil and Water Conservation Society of Metro Halifax, Nova Scotia, p 47

Mariash HL, Smith PA, Mallory M (2018) Decadal response of Arctic freshwaters to burgeoning goose populations. Ecosystems 21:1230-1243

Marsz AA, Styszyńska A (eds) (2013) Climate and climate change at Hornsund, Svalbard. Gdynia Maritime University, Gdynia, p 402

Merritt RW, Cummins KW (eds) (1996) An introduction to the aquatic insects of North America. Kendall-Hunt, Dubuque

Meyers PA, Lallier-Vergès E (1999) Lacustrine organic matter records of Late Quaternary paleoclimates. J Paleolimnol 21:345-372

Meyers PA, Teranes JL (2001) Sediment organic matter. In: Last WM, Smol JP (eds) Tracking environmental change using lake sediments, physical and geochemical methods, vol 2. Kluwer Academic Publishers, Dordrecht, pp 239-269

Michelutti N, Wolfe AP, Vinebrooke RD, Rivard B, Briner JP (2005) Recent primary production increases in arctic lakes. Geophys Res Lett 32:19

Michelutti N, Hermanson MH, Smol JP, Dillon PJ, Douglas MS (2007) Delayed response of diatom assemblages to sewage inputs in an Arctic lake. Aquat Sci 69:523-533

Moe B, Stempniewicz L, Jakubas D, Angelier F, Chastel O, Dinessen F, Gabrielsen GW, Hanssen F, Karnovsky NJ, Rønning B, Welcker J, Wojczulanis-Jakubas K, Bech C (2009) Climate change and phenological responses of two seabird species breeding in the high-Arctic. Mar Ecol Prog Ser 393:235-246

Nesje A, Matthews JA, Dahl SO, Berrisford MS, Andersson C (2001) Holocene glacier fluctuations of Flatebreen and winter-precipitation changes in the Jostedalsbreen region, western NorWay, based on glaciolacustrine sediment records. Holocene 11:267-280

Nevalainen L (2012) Distribution of benthic microcrustaceans along a water depth gradient in an Austrian Alpine lake-Sedimentary evidence for niche separation. Limnologica 42:65-71

Nevalainen L, Luoto TP (2017) Relationship between cladoceran (Crustacea) functional diversity and lake trophic gradients. Funct Ecol 31:488-498

Nevalainen L, Rantala MV, Luoto TP, Rautio M, Ojala AEK (2015) Ultraviolet radiation exposure of a high arctic lake in Svalbard during the Holocene. Boreas 44:401-412

Nevalainen L, Rantala MV, Luoto TP, Ojala AE, Rautio M (2016) Long-term changes in pigmentation of arctic Daphnia provide potential for reconstructing aquatic UV exposure. Quat Sci Rev $144: 44-50$

Nowiński K, Wiśniewska-Wojtasik B (2006) Diversity of abiotic properties of water in shallow lakes in Hornsund area (SW Spitsbergen). Limnol Rev 6:215-222

O'Hanlon NJ, James NA, Masden EA, Bond AL (2017) Seabirds and marine plastic debris in the northeastern Atlantic: a synthesis and recommendations for monitoring and research. Environ Pollut 321:1291-1301

Ojala AEK, Arppe L, Luoto TP, Wacker L, Kurki E, Zajączkowski M, Pawłowska J, Damrat M, Oksman M (2016) Sedimentary environment, lithostratigraphy and dating of sediment sequences from Arctic lakes Revvatnet and Svartvatnet in Hornsund, Svalbard. Pol Polar Res 37:23-48

Ojala AEK, Luoto TP, Virtasalo JJ (2017) Establishing a high-resolution surface sediment chronology with multiple dating methods-testing ${ }^{137} \mathrm{Cs}$ determination with Nurmijärvi clastic-biogenic varves. Quat Geochronol 37:32-41

Passy SI (2007) Diatom ecological guilds display distinct and predictable behavior along nutrient and disturbance gradients in running waters. Aquat Bot 86:171-178

Paul CA, Douglas MSV, Smol JP (2010) Diatom-inferred Holocene climatic and environmental changes in an unusually subsaline high Arctic nunatak pond on Ellesmere Island (Nunavut, Canada). J Paleolimnol 44:913-929

Pawłowska J, Zajaczkowski M, Lacka M, Lejzerowicz F, Esling P, Pawlowski J (2016) Palaeoceanographic changes in Hornsund Fjord (Spitsbergen, Svalbard) over the last millennium: new insights from ancient DNA. Clim Past 12:1459-1472

Perren BB, Anderson NJ, Douglas MSV, Fritz SC (2012) The influence of temperature, moisture, and eolian activity on Holocene lake development in West Greenland. J Paleolimnol 48:223-239

Peterson CG, Stevenson RJ (1992) Resistance and resilience of lotic algal communities: importance of disturbance timing and current. Ecology 73:1445-1461

Pla-Rabés S, Catalan J (2018) Diatom species variation between lake habitats: implications for interpretation of paleolimnological records. J Paleolimnol 60:169-187

Provencher JF, Vermaire JC, Avery-Gomm S, Braune BM, Mallory ML (2018) Garbage in guano? Microplastic debris found in faecal precursors of seabirds known to ingest plastics. Sci Total Environ 644:1477-1484

Quinlan R, Smol JP (2001) Setting minimum head capsule abundance and taxa deletion criteria in chironomid-based inference models. J Paleolimnol 26:327-342

Quinlan R, Smol JP (2002) Regional assessment of long-term hypolimnetic oxygen changes in Ontario (Canada) shield lakes using subfossil chironomids. J Paleolimnol 27:249-260

Quinlan R, Douglas MSV, Smol JP (2005) Food web changes in arctic ecosystems related to climate warming. Glob Change Biol 11:1381-1386

Rantala MV, Luoto TP, Weckström J, Rautio M, Nevalainen L (2017) Climate drivers of diatom distribution in shallow subarctic lakes. Freshw Biol 62:1971-1985

Renberg I (1991) The HOK-Kajak sediment corer. J Limnol 6:167-170

Rimet F, Bouchez A (2012) Life-forms, cell-sizes and ecological guilds of diatoms in European rivers. Knowl Manag Aquat Ecosyst. https://doi.org/10.1051/kmae/2012018

Rühland K, Priesnitz A, Smol JP (2003) Paleolimnological evidence from diatoms for recent environmental changes in 50 lakes across Canadian Arctic treeline. Arct Antarct Alp Res 35:110-123

Rühland K, Paterson AM, Smol JP (2015) Lake diatom responses to warming: reviewing the evidence. J Paleolimnol 54:1-35

Saros JE, Anderson NJ (2015) The ecology of the planktonic diatom Cyclotella and its implications for global environmental change studies. Biol Rev 90:522-541

Scherer C, Brennholt N, Reifferscheid G, Wagner M (2017) Feeding type and development drive the ingestion of microplastics by freshwater invertebrates. Sci rep 7:17006

Schmera D, Heino J, Podani J, Erôs T, Dolédec S (2017) Functional diversity: a review of methodology and current knowledge in freshwater macroinvertebrate research. Hydrobiologia 787:27-44

Sienkiewicz E, Gąsiorowski M, Migała K (2017) Unusual reaction of diatom assemblage on climate changes during the last millennium: a record from Spitsbergen lake. J Paleolimnol 58:73-87 
Šmilauer P, Lepš J (2014) Multivariate analysis of ecological data using CANOCO 5. Cambridge University Press, Cambridge

Smol JP (2010) The power of the past: using sediments to track the effects of multiple stressors on lake ecosystems. Freshw Biol 55:43-59

Smol JP (2016) Arctic and Sub-Arctic shallow lakes in a multiplestressor world: a paleoecological perspective. Hydrobiologia 778:253-272

Smol JP, Douglas MSV (2007a) Crossing the final ecological threshold in high Arctic ponds. Proc Natl Acad Sci 104:12395-12397

Smol JP, Douglas MSV (2007b) From controversy to consensus: making the case for recent climate change in the Arctic using lake sediments. Front Ecol Environ 5:466-474

Stewart EM, Michelutti N, Blais JM, Mallory ML, Douglas MSV, Smol JP (2013) Contrasting the effects of climatic, nutrient, and oxygen dynamics on subfossil chironomid assemblages: a paleolimnological experiment from eutrophic High Arctic ponds. J Paleolimnol 49:205-219

Sweetman JN, LaFace E, Rühland KM, Smol JP (2008) Evaluating the response of Cladocera to recent environmental changes in lakes from the central Canadian Arctic treeline region. Arct Antarct Alp Res 40:584-591

Szeroczyñska K, Sarmaja-Korjonen K (2007) Atlas of subfossil cladocera from central and northern Europe. Friends of lower Vistula society, Poland

Tammelin M, Kauppila T, Viitasalo M (2017) Factors controlling recent diatom assemblages across a steep local nutrient gradient in central-eastern Finland. Hydrobiologia 799:309-325

Tapolczai K, Bouchez A, Stenger-Kovács C, Padisák J, Rimet F (2016) Trait-based ecological classifications for benthic algae: review and perspectives. Hydrobiologia 776:1-17

Thienpont JR, Rühland KM, Pisaric MF, Kokelj SV, Kimpe LE, Blais JM, Smol JP (2013) Biological responses to permafrost thaw slumping in Canadian Arctic lakes. Freshw Biol 58:337-353

Thienpont JR, Korosi JB, Cheng ES, Deasley K, Pisaric MF, Smol JP (2015) Recent climate warming favours more specialized cladoceran taxa in western Canadian Arctic lakes. J Biogeogr 42:1553-1565
Thompson R, Battarbee RW, O'sullivan PE, Oldfield F (1975) Magnetic susceptibility of lake sediments. Limnol Oceanogr 20:687-698

Vincent WF, Pienitz R (1996) Sensitivity of high-latitude freshwater ecosystems to global change: temperature and solar ultraviolet radiation. Geosci Can 23:4

Vonk JE, Tank SE, Bowden WB et al (2015) Reviews and syntheses: effects of permafrost thaw on Arctic aquatic ecosystems. Biogeosci 12:7129-7167

Wagner M, Scherer C, Alvarez-Muñoz D et al (2014) Microplastics in freshwater ecosystems: what we know and what we need to know. Environ Sci Eur 26:12

Wojczulanis-Jakubas K, Jakubas D, Stempniewicz L (2008) Avifauna of Hornsund area, SW Spitsbergen: present state and recent changes. Pol Polar Res 29:187-197

Wookey PA, Aerts R, Bardgett RD, Baptist F, Bråthen KA, Cornelissen JH, Gough L, Hartley IP, Hopkins DW, Lavorel S, Shaver GR (2009) Ecosystem feedbacks and cascade processes: understanding their role in the responses of Arctic and alpine ecosystems to environmental change. Glob Change Biol 15:1153-1172

Wrona FJ, Johansson M, Culp JM, Jenkins A, Mård J, Myers-Smith IH, Prowse TD, Vincent WF, Wookey PA (2016) Transitions in Arctic ecosystems: ecological implications of a changing hydrological regime. J Geophys Res 121:650-674

Zepp RG, Erickson Iii DJ, Paul ND, Sulzberger B (2007) Interactive effects of solar UV radiation and climate change on biogeochemical cycling. Photochem Photobiol Sci 6:286-300

Zmudczyńska K, Zwolicki A, Barcikowski M, Barcikowski A, Stempniewicz L (2009) Spectral characteristics of the Arctic ornithogenic tundra vegetation in Hornsund area, SW Spitsbergen. Pol Polar Res 30:249-262

Publisher's Note Springer Nature remains neutral with regard to jurisdictional claims in published maps and institutional affiliations. 